\title{
Thyroid hormones response to marcha gait in Mangalarga Marchador horses*
}

\section{Resposta dos hormônios da tireoide após a execução da marcha em equinos da raça Mangalarga Marchador}

\author{
Clarisse Simões Coelho, ${ }^{* *}$ Jonathan Cunha Folador, ${ }^{* * *}$ Bianca Drumond, ${ }^{* * *}$ Vinicius Ricardo Cuña de Souza ${ }^{* * * *}$
}

\begin{abstract}
The aim of this study was to evaluate thyroid hormones response to marcha gait by measuring serum concentrations of total (TT4) and free thyroxine (FT4), and total triiodothyronine (TT3) in Mangalarga Marchador horses. Blood samples were collected from 15 Mangalarga Marchador horses at four different moments: before (M0) and within five minutes (M1), 30 minutes (M2) and 2 hours (M3) after exercise (marcha gait for 40 minutes). Mean values of TT4 were $2.24 \pm 0.36 \mu \mathrm{g} / \mathrm{dL}$ on M0, $2.41 \pm 0.35 \mu \mathrm{g} / \mathrm{dL}$ on M1, $2.76 \pm 1.36 \mu \mathrm{g} / \mathrm{dL}$ on M2 and $2.36 \pm 0.40 \mu \mathrm{g} / \mathrm{dL}$ on M3 $(p=0.2906)$. Mean values of FT4 were $0.78 \pm 0.14 \mathrm{ng} / \mathrm{dL}$ on M0, $0.84 \pm 0.11$ $\mathrm{ng} / \mathrm{dL}$ on $\mathrm{M} 1,0.89 \pm 0.18 \mathrm{ng} / \mathrm{dL}$ on $\mathrm{M} 2$ and $0.85 \pm 0.14 \mathrm{ng} / \mathrm{dL}$ on M3 $(\mathrm{p}=0.2305)$. For TT3, mean values were $0.92 \pm 0.28 \mathrm{ng} / \mathrm{mL}$ on $\mathrm{M} 0,0.99 \pm 0.39 \mathrm{ng} / \mathrm{mL}$ on $\mathrm{M} 1,1.20 \pm 1.07 \mathrm{ng} / \mathrm{mL}$ on $\mathrm{M} 2$ and $0.87 \pm 0.24 \mathrm{ng} / \mathrm{mL}$ on $\mathrm{M} 3$ ( $p=0.4697)$. Analysis of the results revealed that marcha gait did not influence serum mean values of thyroid hormones, although it was observed influence over heart rate and body temperature.
\end{abstract}

Keywords: equine, exercise, marcha, thyroid.

\begin{abstract}
Resumo
O presente estudo teve por objetivo avaliar a resposta dos hormônios da tiroide frente a um exercício físico (provas de marcha) através das mensurações séricas de tiroxina total (T4T) e livre (T4L), e triiodotironina total (T3T) em equinos da raça Mangalarga Marchador. Para tal, foram obtidas amostras de sangue de 15 equinos, da referida raça, em quatro momentos assim definidos: antes (M0) e com 5 minutos (M1), 30 minutos (M2) e 2 horas (M3) após a execução de exercício físico (40 minutos de marcha). Os valores médios para T4T foram de 2,24 $0,36 \mu \mathrm{g} / \mathrm{dL}$ em M0, 2,41 $\pm 0,35 \mu \mathrm{g} / \mathrm{dL}$ em M1, 2,76 $\pm 1,36 \mu \mathrm{g} / \mathrm{dL}$ em M2 e 2,36 $\pm 0,40 \mu \mathrm{g} / \mathrm{dL}$ em M3 ( $p=0,2906)$; para T4L foram de 0,78 $\pm 0,14 \mathrm{ng} / \mathrm{dL}$ em M0, 0,84 $\pm 0,11 \mathrm{ng} / \mathrm{dL}$ em M1, 0,89 $\pm 0,18 \mathrm{ng} / \mathrm{dL}$ em M2 e $0,85 \pm 0,14 \mathrm{ng} / \mathrm{dL}$ em M3 ( $p=0,2305$ ); e para T3T foram de $0,92 \pm 0,28 \mathrm{ng} / \mathrm{mL}$ em M0, $0,99 \pm 0,39 \mathrm{ng} / \mathrm{mL}$ em M1, $1,20 \pm 1,07 \mathrm{ng} / \mathrm{mL}$ em M2 e $0,87 \pm 0,24 \mathrm{ng} /$ $\mathrm{mL}$ em M3 $(p=0,4697)$. A análise dos resultados demonstrou que não houve influência da marcha sobre os valores séricos médios dos hormônios tireoidianos, apesar de haver influência sobre a frequência cardíaca e temperatura corporal.
\end{abstract}

Palavras-chave: equino, exercício, marcha, tireoide.

\section{Introduction}

The exercise is probably the main physiological stimuli and the best example of a normal stressor (Booth, 1991). The proper action of the thyroid hormones is crucial to the regulation of the body metabolism, through the increase in protein and enzymes synthesis, an increase in mitochondrial size and number and an increase in the heart contractile activity. Furthermore, exercise stimulates a rapid glucose absorption in the cells and increment glycolysis, glyconeogenesis and lipid mobilization, increasing fatty free acid availability for oxidation and energy production (McKeever, 2002; Hudecova et al., 2004).

The main active hormone in the thyroid is the triiodothyronine (T3). The thyroxine (T4) is a pre-hormone, and the mono iodination of its external ring produces $75 \%$ of the daily T3 (Canali and Kruel, 2001). The increase in the concentration of these hormones can facilitate the physiological changes observed during exercise (Canali and Kruel, 2001).

Anderson et al. (1998) studied 69 adult equines and registered, respectively, values of $1.56 \pm 0.67 \mu \mathrm{g} / \mathrm{dl}$ for total thyroxine, $0.68 \pm 0.85 \mathrm{ng} / \mathrm{ml}$ for total triiodothyronine, $0.59 \pm 0.32 \mathrm{ng} / \mathrm{dl}$ for free T4 and $3.22 \pm 1.50 \mathrm{pg} / \mathrm{ml}$ for free T3. Breuhaus (2002) has also worked with adult equines and cited values of $1.00 \pm 0.44 \mu \mathrm{g} /$ dl for total thyroxine, $0.64 \pm 0.33 \mathrm{ng} / \mathrm{ml}$ for total triiodothyronine, $0.95 \pm 0.27 \mathrm{ng} / \mathrm{dl}$ for free T4 and $1.75 \pm 0.74 \mathrm{pg} / \mathrm{ml}$ for free T3.

Irvine (1967) described that physical conditioning in equines increased T4 secretion in 38\% for light and $65 \%$ for heavy exercises. This indicates an increase in metabolism and thyroid hormone secretion with training. Garcia and Beech (1986) demonstrated that an increase in T3 and T4 happened one hour after 15 minutes of swimming.

*Recebido em 27 de fevereiro de 2014 e aceito em 24 de março de 2015.

**Programa de Mestrado em Ciência Animal e Curso de Graduação em Medicina Veterinária, Universidade Vila Velha (UVV-ES), Rua Comissário José Dantas de Melo, 21, Vila Velha-ES, CEP:29102-770. Brasil. *Author for correspondence: clarisse.coelho@uvv.br

***Curso de Graduação em Medicina Veterinária (UVV-ES).

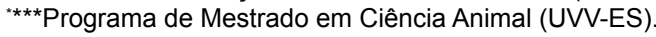

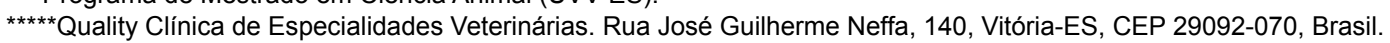


Teixeira and Padua (2002) evaluated hormonal concentration as an indicative of stress in Thoroughbred horses before and after competition. For both variables, the authors described a reduction in the values right after competition (total T3 reduced from 3.35 to $2.60 \mathrm{ng} / \mathrm{ml}$ and total T4 reduced from 9.75 to $7.51 \mu \mathrm{g} /$ dl). Graves et al. (2010) found similar results.

Carter (2005) established the thyroid function in trained horses and ponies with laminitis and described an increase in total T4 (from $0.89 \pm 0.08 \mu \mathrm{g} / \mathrm{dl}$ to $1.46 \pm 0.1 \mu \mathrm{g} / \mathrm{dl}$ ), free T4 (from $0.16 \pm 0.01$ $\mathrm{ng} / \mathrm{dl}$ to $0.3 \pm 0.02 \mathrm{ng} / \mathrm{dl}$ ) and total T3 (from $0.64 \pm 0.04 \mathrm{ng} / \mathrm{ml}$ to $1.08 \pm 0.05 \mathrm{ng} / \mathrm{ml}$ ) after a gallop gait. All the values returned to the pre-exercise values $24 \mathrm{~h}$ latter $(0.85 \pm 0.1 \mu \mathrm{g} / \mathrm{dl}$ for total T4; $0.13 \pm 0.02 \mathrm{ng} / \mathrm{dl}$ for free T4 and $0.63 \pm 0.05 \mathrm{ng} / \mathrm{ml}$ for total T3). Inversely, Suwannachot et al. (2000) did not find alterations in the serum levels of thyroid hormones in ponies Shetland submitted to light exercise with feed ad libitum.

The comprehension of such physiological mechanisms and its characterization are of great importance in the evaluation of the performance of athletic equines (Carter, 2005). The objective of the present study was to evaluate the response of thyroid hormones after the marcha gait through the measurement of total (TT4) and free (FT4) thyroxine, and total triiodothyronine (TT3) in Mangalarga Machador horses.

\section{Material and methods}

This research was approved by the Animal Bioethics Committee from Universidade Vila Velha (18/2011). 15 Mangalarga Machador horses were used, nine females and six males, weighting $399 \pm 34 \mathrm{~kg}$, with mean age of $4.6 \pm 1.9$ years old (310 years old), considered clinically healthy in the physical and blood exams. These animals were located in farms in the Vitoria, Espirito Santo, Brazil (LAT-20'19'10" LONG-40C20'16”). Local average temperature was $24^{\circ} \mathrm{C}$ and humidity $80 \%$. All animals were in the same feed and management conditions.

Animals were fed with coast-cross hay (Cynodon dactylon $x$ Cynodon nlemfluensis) ad libitum and commercial feed (DoEqui TopQuality) with $12 \%$ crude protein (1\% of the body weight), three times a day. Water and mineral salt were given ad libitum.

All animals were in the same training protocol level and they have been on physical activity for at least six months. Training were done by pulling the animal in a halter for $60 \mathrm{~min}$, twice a week, alternating in the other three days with riding exercises, in marcha gait, for $40 \mathrm{~min}$. On weekends horses executed marcha gait for 20 minutes each.

In the present study, the horses executed cadenced marcha, 20 min clockwise and 20 min counterclockwise, in an average speed of nine to $12 \mathrm{~km} / \mathrm{h}$. Blood samples were drawn in four moments: at rest ( $\mathrm{M} 0$, before the beginning of exercise), after exercise 1 (M1, five min after the exercise), after exercise 2 (M2, 30 min after exercise) and after exercise 3 (M3, 2 hours after exercise). All activities were done during the morning, preferentially between 7 and 11 AM. At the moment of blood drawing heart frequency and body temperature were also measured. Two riders were used with mean weight of $70 \mathrm{~kg}$ and height of $1.70 \mathrm{~m}$, both registering horses' performance.
In the day of experiment the characteristics of the track were registered.

Blood samples were drawn after local asepsis, through venopuncture of the jugular with $25 \mathrm{~mm} \times 0.8 \mathrm{~mm}$ needles in vacutainer tubes without anticoagulant. Samples were centrifuged for $10 \mathrm{~min}$ in 3500 RPM to separate the serum.

To determine total T3 and total and free T4 it was used a radioimmunoassay (RIA) with commercial kit Access Immunoassay System (Beckman Coulter) on UniCel DxI 800 Immunoassay System (Beckman Coulter), following manufactures instructions and modifications for equines by Messer et al. (1995). All tests were done in duplicate at the TECSA Laboratórios (Belo Horizonte, MG, Brazil).

Results were analyzed for normality using Kolmogorov-Smirnov test and the variables were analyzed through ANOVA and Tukey test using the statistical program GraphPad InStat (3.0). Differences were considered significant when $p \leq 0.05$. The influence of exercise in the concentration of thyroid hormones was considered in the analysis.

\section{Results}

In the physical exam performed for the selection of the horses used in this experiment, the average values registered were: 45 beats per minute (bpm) for heart rate, 20 movements per minute (mpm) on respiratory rate, normal intestinal motility, pink mucosa and rectal temperature of $37.5^{\circ} \mathrm{C}$. Blood exam showed $7.25 \times 10^{6} /$ $\mu \mathrm{L}$ erythrocytes, $11.99 \mathrm{~g} / \mathrm{dL}$ for hemoglobin concentration, $35 \%$ for packed cell volume, $49.01 \mathrm{fl}$ for mean corpuscular volume and 9533 leucocytes/ $\mu \mathrm{L}$.

The equines were exercised during three days. The local temperature is typical of tropical region, with high temperatures and humidity. The grass track was dry at the moment of exercise. According to the trainer, all animals presented normal athletic performance.

Table 1 shows means and standard deviation for heart rate, body temperature, serum concentrations of TT4, FT4 and TT3 and $p$ values analyzed by ANOVA. Data shows that the athletic exercise imposed through the marcha gait did not influence the values of the thyroid hormones ( $p>0.05)$, although it influenced heart rate and body temperature $(p<0.05)$.

Table 1: Mean values and standard deviation of heart rate (HR), body temperature (BT), serum concentrations of total (TT4) and free (FT4) tiroxine and total triiodotironine (TT3) in Mangalarga Machador horses in moments M0, M1, M2 and M3 after the execution of the marcha gait for 40 minutes

\begin{tabular}{lccccc}
\hline & M0 & M1 & M2 & M3 & $p$ \\
\hline HR $(\mathrm{bpm})$ & $44.8 \pm 8.2^{\star \mathrm{a}}$ & $100.5 \pm 22.4^{\mathrm{b}}$ & $53.1 \pm 8.6^{\mathrm{a}}$ & $46.4 \pm 7.6^{\mathrm{a}}$ & $<0.0001$ \\
BT $\left({ }^{\circ} \mathrm{C}\right)$ & $37.5 \pm 0.5^{\mathrm{a}}$ & $40.0 \pm 0.8^{\mathrm{c}}$ & $38.7 \pm 0.7^{\mathrm{b}}$ & $37.6 \pm 0.4^{\mathrm{a}}$ & $<0.0001$ \\
TT4 $(\mu \mathrm{g} / \mathrm{dL})$ & $2.24 \pm 0.36^{\mathrm{a}}$ & $2.41 \pm 0.35^{\mathrm{a}}$ & $2.76 \pm 1.36^{\mathrm{a}}$ & $2.36 \pm 0.40^{\mathrm{a}}$ & 0.2906 \\
FT4 $(\mathrm{ng} / \mathrm{dL})$ & $0.78 \pm 0.14^{\mathrm{a}}$ & $0.84 \pm 0.11^{\mathrm{a}}$ & $0.89 \pm 0.18^{\mathrm{a}}$ & $0.85 \pm 0.14^{\mathrm{a}}$ & 0.2305 \\
TT3 $(\mathrm{ng} / \mathrm{mL})$ & $0.92 \pm 0.28^{\mathrm{a}}$ & $0.99 \pm 0.39^{\mathrm{a}}$ & $1.20 \pm 1.07^{\mathrm{a}}$ & $0.87 \pm 0.24^{\mathrm{a}}$ & 0.4697 \\
\hline
\end{tabular}

* Different lower case letters in the same line indicate statistical difference by the Tukey test. M0 (before training, with the animal at rest, between 7AM and 11AM), M1 (5 min after the end of training), M2 (30 min after the end of training) and M3 (30 min after the end of training). 


\section{Discussion}

According to Robinson (2009), all values recorded for the selection of the animals were considered normal for equines, but hematological variables were different from those described by Holanda et al. (2013) studying only Mangalarga Marchador horses. On the present research, horses had been on a training program while Holanda et al. (2013) used animals for reproduction purposes in their experiment.

The basal results (M0) of TT4 and TT3 in the present experiment were superior from the ones registered by Anderson et al. (1998), Breuhaus (2002) and Carter (2005) for health adult equines. However, for F4T they were similar. It is hard to determine a reference interval and classify the measurements as normal due to the high variation in the basal levels for thyroid hormones in horses.

The results described in the literature that correlates thyroid evaluation and exercise are conflicting and limited. According to Canali and Kruel (2001) and Mckeever (2002), the exercise leads to an increase in the release of the thyroid hormones to attend the organic demands to facilitate muscle contraction (Hudecova et al., 2004). This raise on organic metabolism is expected and was observed on horses of the present study after marcha gait through significant elevation of both body temperature and heart rate soon after the end of exercise. Even though, animals were considered adapted to the level of imposed exercise, as the clinical examination (heart rate returned to basal levels 30 minutes after exercise) and performance did not show any alteration. Additionally, lactate analysis revealed values of $1.02 \pm 0.41 \mathrm{mmol} / \mathrm{L}$ at $\mathrm{M} 0,2.73 \pm 2.43 \mathrm{mmol} / \mathrm{L}$ at $\mathrm{M} 1,1.89 \pm 1.24$ $\mathrm{mmol} / \mathrm{L}$ at $\mathrm{M} 2$ and $1.31 \pm 0.60 \mathrm{mmol} / \mathrm{L}$ at $\mathrm{M} 3$ and $\mathrm{CK}$ levels of $113.4 \pm 56.3 \mathrm{UI} / \mathrm{l}$ at $\mathrm{M0}, 144.1 \pm 70.9 \mathrm{UI} / \mathrm{L}$ at M1, 143.0 $\pm 81.0 \mathrm{UI} / \mathrm{L}$ at M2 and 173.1 $\pm 128.0 \mathrm{UI} / \mathrm{L}$ at M3, data already published by Gama et al. (2012). According to Irvine (1983), both hypothyroidism and hyperthyroidism can promote moderate muscular insufficiency. In the hypothyroidism, it can occur myopathy with increase in creatinekinase $(\mathrm{CK})$ and in the hyperthydoidism there is hypersensibility and increased response to the sympathetic nervous system (tachycardia, hyperkinesis, fatigue and reduction in the capacity to exercise). Corroborating with these information, equines thiroidectomized presented a reduction in heart and respiratory frequency and in cardiac output at rest (Frank et al., 2002) and also intolerance to exercise (Carter, 2005).

Gonzales et al. (2010), evaluating Thoroughbred horses, described an increase in T3 (from $55.6 \mathrm{ng} / \mathrm{dl}$ to $81 \mathrm{ng} / \mathrm{dl}$ ), but no alteration on T4. This increase happened five min after the beginning of the exercise, demonstrating the rapid response to the exercise. In another study, after prolonged submaximum exercises the concentration of T4 remained the same, 35\% superior to the basal values, after five min of exercise (Canali and Kruel, 2001). Garcia and Beech (1986), Irvine (1967) and Carter (2005) had similar results.
These results are different from Teixeira and Padua (2002) that also worked with Thoroughbred horses and registered a reduction in the values of TT3 and TT4 immediately after the end of the exercise. These authors justified the greater utilization of these hormones in consequence of the great energetic contribution, without having a reposition of these hormones by the gland.

On the present research, differently from the researchers cited above, it was not observed a significant influence of the marcha gait in the thyroid hormones concentration, although higher numerical values of TT4, FT4 and TT3 were observed 30 min (M2) after the end of the marcha gait. This difference can be due intensity and duration of exercise. According to Carter (2005) and Schrauwen and Hesselink (2003), acute exercise (high speed and rapid or moderated duration) regulates positively decoupling proteins leading to an increase in the hormonal concentration; and exercises like endurance (and in a similar way, marcha gait) negatively regulate the decoupling proteins, leading to a reduction, or even no modification, of hormone levels after exercise. Carter's (2005) report demonstrated a significant increase in the hormones after the gallop, using equines in an average speed of $28.8 \mathrm{~km} / \mathrm{h}$, in contrast to the $9-12 \mathrm{~km} / \mathrm{h}$ speed used in this experiment.

Graves et al. (2010) evaluated the thyroid response after resistance exercise (endurance) in equines and highlighted the little information available in the literature. On $56 \mathrm{~km}$ distance runs, only FT4 showed a reduction of $10 \%$ in the values after exercise. On the other hand, there was a reduction in all the studied variables (TT4, FT4, TT3 and FT3) between 13-31\% and $47-54 \%$, respectively, to the distances of 80 to $160 \mathrm{~km}$, confirming what was proposed for exercises of low speed and long duration. These concentrations were transitory, as said earlier, with the return of the concentrations to basal levels $24 \mathrm{~h}$ after the end of the exercise.

Therefore, McKeever (2002) highlights that the liberation of TSH is related to the intensity of exercise, and lighter and moderated exercise, as the marcha gait, would not influence its release and, consequently, production of thyroid hormones.

The conflicting information found in the literature reinforce that more research are necessary to a more reliable interpretation of the data. It is important to highlight that the determination of the serum free and total T3 and T4 indicate only the activity of the thyroid gland after an imposed physical exercise (Carter, 2005); its action in their target cells depend on factors such as coupling proteins and transport to the cells, for example.

\section{Conclusion}

The results from the present research allowed us to conclude that the imposed exercise (marcha) did not influence the serum values of the T3 and T4 hormones.

Additionally, these findings can contribute with those rare reports described in the literature considering Mangalarga Marchador breed, when raised and worked in tropical conditions. 


\section{References}

ANDERSON, R.R.; NIXON, D.A.; AKASHA, M.A. Total and free thyroxine and triiodothyronine in blood serum of mammals. Comp. Biochem. Physiol. A, v. 89, n. 3, p .401-404, 1988.

BOOTH, F.W.; THOMASON, D.B. Molecular and cellular adaptation of muscle in response to exercise: perspectives of various models. Physiol. Reviews, v. 71, n. 2, p. 541-585, 1991.

BREUHAUS, B.A. Thyroid-stimulating hormone in adult euthyroid and hypothyroid horses. J. Vet. Intern. Med., v. 16, n. 1, p. 109115,2002

CANALI, E.S.; KRUEL, L.F.M. Respostas hormonais ao exercício. Revista Paul. Educ. Fis.,v. 15, n. 2, p.141-153, 2001.

CARTER, R.A. Thyroid status in exercising horses and laminitic ponies. 2005. 109 f. Dissertação (Mestrado) - Virginia Polytechnic Institute and State University, Virginia, 2005.

FRANK, N.; SOJKA, J.; MESSER, N. Equine thyroid dysfunction. Vet. Clin. Equine Pract ., v. 18, n. 2, p. 305-319, 2002.

GAMA, J.A.N.; SOUZA, M.S.; PEREIRA NETO, E.; SOUZA, V.R.C.; COELHO, C.S. Concentrações séricas de aspartato aminotransferase e creatinoquinase e concentrações plasmaticas de lactato em equinos da raça Mangalarga Marchador após exercício físico. Braz. J. Vet. Res. Anim. Sci., v. 49, n. 6, p. 480486, 2012.

GARCIA, M.C.; BEECH, J. Endocrinologic, hematologic, and heart rate changes in swimming horses. Am. J. Vet. Res., v. 47, n. 9, p. 2004, 1986.

GONZALEZ, O.; GONZALEZ, E.; SANCHEZ, C.; PINTO, J.; GONZALEZ, I.; ENRIQUEZ, O.; MARTINEZ, R.; FILGUEIRA, G.; WHITE, A. Effect of exercise on erythrocyte b-adrenergic receptors and plasma concentrations of cathecolamines and thyroid hormones in Thoroughbred horses. Equine Vet. J., v. 30, n. 1, p. 72-78, 2010.

GRAVES, E.A.; SCHOTT, H.C.; MARTENIUK, J.V.; REFSAL, K.R.; NACHREINER, R.F. Thyroid hormone responses to endurance exercise. Equine Vet. J., v. 36, p. 32-36, 2010.
HOLANDA, L.C.; VAZ, S.G.; ALMEIDA, T.L.A.C.; MELO, S.K.M.; LIRA, L.B.; SANTOS, F.L.; REGO, E.W.; TEIXEIRA, M.N.

Variáveis hematológicas de equinos (Equus caballus, Linnaeus, 1958) da raça Mangalarga Marchador. Medicina Veterinária, v. 7 , n. 3, p. 1-6, 2013.

HUDECOVA, S.; VADASZOVA, A.; SOUKUP, T.; KRIZANOVA, $O$. Effect of thyroid hormones on the gene expression of calcium transport systems in rat muscles. Life Sci., v. 75, n. 8, p. 923-931, 2004.

IRVINE, C.H. Thyroxine secretion rate in the horse in various physiological states. J. Endocrinol., v. 39, n. 3, p. 313, 1967.

McKEEVER, K.H. The endocrine system and the challenge of exercise. Vet. Clin. North Am. Equine Pract., v. 18, n. 2, p. 321353, 2002.

MESSER, N.T.; JOHNSON, P.J.; REFSAL, K.R.; NACHREINER, R.F.; GANJAM, V.K.; KRAUSE, G.F. Effect of food deprivation on baseline iodothyronine and cortisol concentrations in healthy, adult horses. Am. J. Vet. Res., v. 56, n.1, p. 116-121, 1995.

ROBINSON, E.N. Current Therapy in Equine Medicine. 6. ed. United States of America: W.B. Saunders, 2009, 1066 p.

SCHRAUWEN, P.; HESSELINK, M. Uncoupling protein 3 and physical activity: the role of uncoupling protein 3 in energy metabolism revisited. Proc. Nutr. Soc., v. 62, n. 3, p. 635-643, 2003.

SUWANNACHOT, P.; VERKLEIJ, C.; KOCSIS, S.; ENZERINK, E.; EVERTS, M. Prolonged food restriction and mild exercise in Shetland ponies: effects on weight gain, thyroid hormone concentrations and muscle $\mathrm{Na}+, \mathrm{K}+-$ ATPase. J. Endocrinol., v.167, n. 2, p. 321-329, 2000.

TEIXEIRA, P.P.; PÁDUA, J.T. Avaliação dos níveis de cortisol, tiroxina, triiodotironina e glicose como indicativos de estresse em cavalos Puro Sangue Inglês de corrida, antes e após a competição. Ciênc. Anim. Bras., v. 3, n. 1, p. 39-48, 2002. 